1 ORIGINAL RESEARCH

2 Zen et al

\title{
3 A Multi-center Study of COVID-19 with Multivariate Prognostic
}

4 Analysis

5

6 Wen Zeng* ${ }^{1}$

$7 \quad$ Xin Feng $*^{1}$,

8 Jie Huang $*^{2}$

9 Chuan $\mathrm{Du}^{*^{3}}$

10 Dongming $\mathrm{Qu}^{* 4}$

11 Xiang Zhang ${ }^{5}$

12 Jianquan Zhang $^{1}$

131 Department of Respiratory and Critical Care Medicine, The First Affiliated Hospital of Guangxi Medical

14 University, Nanning, Guangxi 530021, China

$15 \quad{ }^{2}$ The Fourth People's Hospital of Nanning City, Nanning, Guangxi, 530021, China

$16{ }^{3}$ Hubei No.3 People's Hospital of Jianghan University, Wuhan, Hubei,430000, China

$17{ }^{4}$ Nanxishan Hospital of Guangxi Zhuang Autonomous Region, Guilin, Guangxi, 541000, China

$18{ }^{5}$ Wuhan Huangpi District Hospital of Traditional Chinese Medicine, Wuhan, Hubei, 430000, China

$19 *$ These authors contributed equally to this project and should be considered co-first authors.

20 Correspondence:

21 Jianquan Zhang, MD, $\mathrm{PhD}$

22 Department of Respiratory and Critical Care Medicine,1 Guangxi 530021, China

23 E-mail: jqzhang2002@126.com

$24 \quad$ Tel.: +86 13978123845

25 Fax: +8607715350031 


\section{Abstract:}

28 Purpose: Coronavirus disease (COVID-19) pandemic is now a global health concern.

29 However, there is no detailed analysis of the factors related to patients' improvement.

30 Patients and methods: We compared the clinical characteristics, laboratory findings, CT 31 images, and treatment of COVID-19 patients from two different cities in China. One hundred 32 and sixty-nine patients were recruited from January 27 to March 17, 2020 at five hospitals in 33 Hubei and Guangxi. They were divided into four groups according to age and into two groups according to presence of comorbidities. Multivariate statistical analyses were performed for the prognosis of the disease.

Results: Fifty-two patients $(30.8 \%)$ had comorbidities, and the percentage of critical COVID-19was higher in the comorbidities group (11.6\%vs.0.9\%, $\mathrm{p}<0.05)$. Older patients had higher proportion of severe or critical disease. The results showed that lymphocyte count was significantly associated with the number of days from positive COVID-19 nucleic acid test to negative test; number of days from onset of symptoms to confirmation of diagnosis was significantly associated with the time it took for symptoms to improve; and number of days from onset of symptoms to confirmation of diagnosis and disease severity were significantly associated with chest computed tomography improvement.

Conclusions: Age, comorbidities, lymphocyte count, and $\mathrm{SpO}_{2}$ may predict the risk of severity of COVID-19. Early isolation, early diagnosis, and early initiation of management can slow down the progression and spread of COVID-19.

48 Keywords: COVID-19; Severity; Multiple lung lobe involvement, prognosis 
medRxiv preprint doi: https://doi.org/10.1101/2020.09.26.20202234; this version posted September 28, 2020. The copyright holder for this

49 Key Points: Age and comorbidities can predict the risk of severity of COVID-19,

50 Lymphocyte count and $\mathrm{SpO}_{2}$ may predict the risk of severity of COVID-19. Early isolation,

51 Early diagnosis can slow down the progression of COVID-19

\section{$53 \quad$ 1.Introduction}

54 Coronavirus disease 2019 (COVID-19), which is caused by severe acute respiratory syndrome

55 coronavirus2 (SARS-CoV-2), has spread throughout the world, posing a critical threat to

56 global health. COVID-19 has been declared as a public health emergency by the World Health

57 Organization, and 3,175,207 laboratory-confirmed infections had been reported globally by

58 May 1, 2020.1 Several studies have described the clinical characteristics and epidemiology of

59 COVID-19.2-6 The novel corona virus has caused clusters of severe respiratory illness, similar

60 to severe acute respiratory syndrome coronavirus.2,5Previous studies have also summarized

61 the early clinical, laboratory, and computed tomography (CT)findings of COVID-19

62 pneumonia.3,6A multi-center study of clinical features showed that multiple organ dysfunction

63 and impaired immune function were the typical characteristics of severe and critical disease,

64 and advanced age ( $\geq 75$ years) was a risk factor for mortality.4However, there is no detailed

65 analysis of the factors related to patients' improvement. In this study, we analyzed the clinical

66 features, laboratory findings, CT images, outcomes, and therapies (including antiviral drugs,

67 antibacterial drugs, and corticosteroids)in 169 COVID-19 cases from three cities (Nanning and

68 Guilin in Guangxi Province, and Wuhan in Hubei Province).We also analyzed the factors

69 related to patients' improvement. 
medRxiv preprint doi: https://doi.org/10.1101/2020.09.26.20202234; this version posted September 28, 2020. The copyright holder for this

\section{$71 \quad$ 2.Methods}

72 2.1. Study design and participants

73 Patients who were $\geq 18$ years old were recruited for this multi-center retrospective study from

74 five hospitals designated for the treatment of COVID-19 in China, namely Guangxi Medical

75 University First Affiliated Hospital and The Fourth People's Hospital of Nanning City, both in

76 Nanning; Nanxishan Hospital of Guangxi Zhuang Autonomous Region, in Guilin, Guangxi

77 Province; and Wuhan Huangpi District Hospital of Traditional Chinese Medicineand Hubei

78 No.3 People's Hospital of Jianghan University, bothin Wuhan, Hubei Province. The

79 recruitment period was from January 27 to March 17, 2020. All patients enrolled in this study

80 were diagnosed with COVID-19 according to the diagnostic criteria from the Chinese Clinical

81 Guidance for COVID-19 Pneumonia Diagnosis and Treatment(7th edition), which was

82 produced by the National Health Commission of China.7 The study was approved by the

83 Research Ethics Commission of Guangxi Medical University First Affiliated Hospital

84 approval number: 2020(KY-E-06).

85 We grouped the patients according to their ages into group A (18-44 years), group B (45-64

86 years), group C (64-74 years), and group D (>75 years).Analysis of prognosis of improvement

87 included three aspects: number of days from positive COVID-19 nucleic acid test to negative

88 test, number of days from onset of illness(the first day of presenting with COVID-19-related symptoms, such as fever, cough, and diarrhea)to improvement in symptoms, and improvement

90 on the second CT scan. The primary outcomes were improvement and death. 
medRxiv preprint doi: https://doi.org/10.1101/2020.09.26.20202234; this version posted September 28, 2020. The copyright holder for this

93 According to the Chinese Clinical Guidance for COVID-19 Pneumonia Diagnosis and

94 Treatment (7th edition), COVID-19 is classified by severity into mild, moderate, severe, and

95 critical types.7

96

97 2.3. Data collection

98 The medical records of the recruited COVID-19 patients were reviewed and general

99 information, epidemiological data, and data on clinical presentation, laboratory tests, chest CT

100 scan findings, treatment modalities, and outcome were collected. Clinical data collection was

101 completed on March 17, 2020. Du Chuang and Huang Jie cross-checked the data. The local

102 Center for Disease Control (CDC) laboratories made definitive diagnosis of COVID-19 by

103 analyzing throat-swab specimens from the upper respiratory tract or feces. Real-time reverse

104 transcription polymerase chain reaction (RT-PCR) was used to confirm COVID-192 and

105 exclude other viral infections. All patients underwent chest CT scan. Two attending

106 radiologists were invited to interpret all chest CT scans independently, and they were blinded

107 to the clinical information of each patient. The following CT features were assessed:

108 distribution of lesions (peripheral, along the bronchi, random, or diffuse), number of lobes

109 involved (one, two or three, or four or five), shape of lesions (patchy or nodular), appearance

110 (ground-glass opacity [GGO], consolidation, or GGO with consolidation), specific focal signs

111 (vascular thickening, crazy paving pattern, and fibrosis), and extrapulmonary manifestations

112 (mediastinal and hilar lymph node enlargement, pleural effusion, or pleural thickening).In case

113 of discordance between the interpretations of the two radiologists, the opinion of a third deputy

114 chief physician radiologist was sought to reach a final decision. Data on follow-up, prognosis, 
medRxiv preprint doi: https://doi.org/10.1101/2020.09.26.20202234; this version posted September 28, 2020. The copyright holder for this

115 and treatment were updated on April 24, 2020.

116 2.4. Statistical analyses

117 Continuous variables were expressed as medians with interquartile ranges (IQR), and 118 categorical variables were reported as frequencies and percentages. Differences between 119 groups were compared using the independent samples t-test or Mann-Whitney test. The single 120 factor analysis of variance (ANOVA) or Kruskal-Wallis $\mathrm{H}$ test was used, as appropriate, to 121 compare the difference among the four groups into which patients were divided based on 122 severity of the disease. Least significant difference (LSD) or Dunn's test was used for post hoc 123 comparisons. Categorical data were analyzed either with Pearson Chi-square test or with

124 Fisher's exact test. Two-tailed tests were performed to determine statistical significance at the $1255 \%$ level. Bonferroni correction was used for pairwise comparison.

126 Univariable and multivariable analyses for factors associated with the time for nucleic acid test 127 to turn negative and the time of improvement of symptoms were performed with multiple 128 linear regression analyses. Univariable and multivariable analyses for factors that are 129 associated with chest CT improvement were done with Kaplan-Meier method and Cox 130 proportional hazards regression model. Univariable and multivariable analyses for risk factors 131 for disease severity and the relationship between age and disease severity were performed with 132 logistic regression analyses. All data analyses were carried out using IBM Statistical Package 133 for the Social Sciences for Windows, version 25 (SPSS Inc., Chicago, Illinois), and graphs 134 were created using GraphPad Prism 7.0 software (GraphPad Software Inc., San Diego, CA, 135 USA). P value less than 0.05 was considered statistically significant.

\section{Results}


medRxiv preprint doi: https://doi.org/10.1101/2020.09.26.20202234; this version posted September 28, 2020. The copyright holder for this preprint (which was not certified by peer review) is the author/funder, who has granted medRxiv a license to display the preprint in perpetuity. All rights reserved. No reuse allowed without permission.

137 The median age of the patients was 52.8 years (IQR, 19-82). Male patients accounted for

$46.7 \%$ of all patients. Based on severity, 12 patients (7.1\%) had mild COVID-19,137(81.1\%)

patients had moderate type, $13(7.7 \%)$ patients had severe type, and $7(4.1 \%)$ patients had critical type. The median number of days from the onset of illness to admission was 11.6 days (IQR, 18-92).Fifty-two patients had comorbidities, including hypertension, cardiovascular disease, diabetes, malignancy, cerebrovascular disease, chronic obstructive pulmonary disease(chronic obstructive pulmonary disease),chronic nephropathy, immunosuppression, and others. The most common morbidity was hypertension(17.8\%). Clinical symptoms included fever, cough, sputum production, dry cough, pharyngalgia, shortness of breath, hemoptysis, myalgia, digestive symptoms, hypodynamia, and others. Fever was the most common symptom $(76.9 \%)$, followed by dry cough (68\%). Among the 169 patients, the lymphocyte count was decreased in $111(65.68 \%)$ patients (median=1.24 (IQR=0.18-4.11) $\times 109 / \mathrm{L})$. C-reactive protein $(\mathrm{CRP})$ increased in $102(65.39 \%)$ patients, lactate dehydrogenase (LDH) increased in $52(33.33 \%)$ patients, and D-dimer increased in 55 (35.95\%) patients. Alanine transaminase or aspartate aminotransferase was elevated in 56 patients $(33.17 \%)$. Serum creatinine was elevated in 5 patients (2.96\%), 4 patients had chronic nephropathy, and 1 patient's renal function returned to normal after treatment. One hundred and fifty-four $(90.1 \%)$ patients received antiviral therapy within the first 3 days. Antivirals used included lopinavir, tonavir, abidor, ribavirin, ganciclovir, and oseltamivir. Most patients (53.9\%) received antibacterial therapy, including moxifloxacin, cephalosporins, and azithromycin. Forty-eight (28.4\%) patients received corticosteroids. One hundred and sixty-five (97.60\%) patients improved, while four patients died. 
medRxiv preprint doi: https://doi.org/10.1101/2020.09.26.20202234; this version posted September 28, 2020. The copyright holder for this who died were all in Wuhan group (Table 1).

Among the 4 age groups into which patients were stratified, groups C and D had higher proportions of severe and critical disease than the other 2 groups, and group $\mathrm{C}$ had the highest proportion of severe disease among the 4 groups. Group A had the least proportion of patients with dyspnea, while group $\mathrm{C}$ had the highest. In both group $\mathrm{C}$ and group $\mathrm{D}$, oxygen saturation(SpO2)was lower than 94\%, and group $\mathrm{C}$ had the lowest $\mathrm{SpO}$. The lymphocyte count was lower in groups $\mathrm{C}$ and D than in groups A and B. LDH in group A was the lowest. CRP, pro-calcitonin (PCT), and interleukin (IL)-6 were significantly higher in groups C and D than in groups A and B. (Table2).

173 Fifty-two patients (30.8\%) in the study had comorbidities. Compared with patients who had no 174 comorbidities, the percentage of critical COVID-19 was higher in the comorbidities 175 group(11.6\%vs.0.9\%; $\mathrm{p}<0.05)$.Patients with comorbidities were also more likely to have dyspnea(36.5\% vs. $16.2 \%$; $<$ 0.05).The total protein and albumin values and lymphocyte

177 counts in patients with comorbidities were lower, while increase in CRP and LDH was more 178 obvious in this group.All4 patients who died had comorbidities(Table3).

179 To determine the association of disease severity with age, we divided all patients into 5 groups 180 at intervals of 15 years, and analyzed the frequencies of severe and critical disease. We found 
medRxiv preprint doi: https://doi.org/10.1101/2020.09.26.20202234; this version posted September 28, 2020. The copyright holder for this preprint (which was not certified by peer review) is the author/funder, who has granted medRxiv a license to display the preprint in perpetuity.

All rights reserved. No reuse allowed without permission.

181

182

183

that older patients had higher proportion of severe or critical disease(Table 4).The 169 patients were also divided into two groups-mild group(including mild type and moderate type COVID-19,n=148) and severe group(including severe and critical type COVID-19, $\mathrm{n}=21$ ) —and we then analyzed the risk factors for disease severity. The results showed that lymphocyte count and $\mathrm{SpO} 2$ at admission were factors that determined the risk factor of disease severity (Table5).

A total of 116 patients with CT image data were enrolled in this study. The average time from onset of illness to CT imaging was 10.73 \pm 7.97 ( 0-34 ) days. The first CT imaging findings of the 116 patients were analyzed, and we found that $84(72.41 \%)$ patients had bilateral lung involvement,88(75.86\%) patients hadperipheral lesions, and99(85.3\%) patients had involvement of two or more lung lobes. The most common CT features were consolidation (66.4\%), GGO (55.2\%), linear opacity (55.20\%), and mixed GGO and consolidation (33.60\%). Forty (34.48\%) patients had vascular thickening.

We further divided the patients into 6 groups according to the number of days from onset of illness to repeat chest CT imaging: group1( $\leq 7$ days, $n=59)$, group2(8-14days, $n=92$ ), group3(15-21days, $\mathrm{n}=109)$, group4(22-28days, $\mathrm{n}=60$ ), group5(29-45days, $\mathrm{n}=52$ ), and group6(46-60days, $\mathrm{n}=18$ ). Among the groups, group 1 had the highest percentage of GGO (48cases, $81.4 \%$ ), and the least percentage of linear opacity (20cases, 33.9\%). Group 2 had the highest percentage of consolidation (72cases,78.3\%). The proportion of cases with linear opacity gradually increased from group1 to group6, reaching $98.1 \%$ in group6.There were 4 casesof reticular changes in group 1 ,and the proportion gradually increased to group 6 , in which there were 7 cases(Table 6). 
medRxiv preprint doi: https://doi.org/10.1101/2020.09.26.20202234; this version posted September 28, 2020. The copyright holder for this preprint (which was not certified by peer review) is the author/funder, who has granted medRxiv a license to display the preprint in perpetuity. All rights reserved. No reuse allowed without permission.

203 To monitor the changes in CT images during the course of the disease, we considered the 204 dynamic changes in the CT images of two patients from Guangxi, from onset to improvement 205 of the disease: one with severe disease (patient1, Figure1) and the other with moderate disease 206 (patient 2, Figure 2). As shown in Figure 1, patient 1 had ground glass opacity on chest CT in 207 the early stage of the disease, and consolidation was noted on chest CT done on day 13 from onset of illness, as the patient's clinical symptoms improved. Consolidation had resolved on 209 day 18 from onset of illness. Finally, the patient had linear opacity on day 23 from onset of 210 illness. There were fifty-one patients when their clinical symptoms improved and they had checked chest CT (no more than 1 day before and after). Among them, the first CT findings

212 were mainly GGO in 36 cases. When their clinical symptoms improved, 16 cases (44.4\%) 213 showed resolution of ground glass opacities but increased consolidation on repeat CT imaging, 214 while16 cases (44.4\%) showed both GGO and resolution of consolidation.

215 All 169 patients had positive real-time RT-PCR for COVID-19 nucleic acid on nasopharyngeal swab specimens. Twenty-five patients underwent nucleic acid test on stool samples: seven of them were positive, and six among them had diarrhea. Twenty patients underwent nucleic acid 218 test of urine samples: one was positive, but he did not have symptoms of urinary tract infection.

219 Vaginal secretions and semen tests were performed in 6 patients, all of which were negative.

220 We designed three prognostic models: model 1 was based on number of days from positive 221 COVID-19 nucleic acid test to negative test, model 2 was based on number of days from onset 222 of illness to improvement in symptoms, and model 3 was based on whether the second CT scan was better than the first. There were 79 cases included in model 1, and multivariable analysis 224 showed that lymphocyte count was significantly associated with the number of independent 
medRxiv preprint doi: https://doi.org/10.1101/2020.09.26.20202234; this version posted September 28, 2020. The copyright holder for this

225 risk factor of days for positiveCOVID-19 nucleic acid test to become negative(Table 7, Figure

226 3). There were 53 cases included in model 2 , and multivariable analysis showed that number of

227 days from onset of illness to confirmation of diagnosis was significantly associated with an

228 independent risk factor of the time it took for symptoms to improve (Table 8, Figure 4). The

229 average number of days from the first CT scan to the second CT scan was 5.35 days, and we

230 took 6 days as the time point for evaluating whether the CT scans improved or not. A total of 62

231 patients were included in model 3, and multivariable analysis showed that number of days from

232 onset of illness to confirmation of diagnosis and disease severity were significantly associated

233 with independent risk factors of chest CT improvement (Table 9).

\section{4. Discussion}

235 This study summarizes the clinical characteristics, laboratory findings, dynamic changes in CT 236 images, treatment, and prognosis of 169 COVID-19 patients from 5 hospitals in a western

237 China city and in the city of disease onset, Wuhan. The study included mostly mild cases of

238 COVID-19, which accounted for $88.2 \%$. We analyzed the disease progression in three ways:

239 number of days from positive COVID-19 nucleic acid test to negative test, number of days

240 from onset of illness to improvement in symptoms, and improvement in second CT scan

241 compared to the first. At present, no similar large sample data has been reported.

242 The study showed that the common symptoms of COVID-19 were fever, cough, sputum

243 production, dyspnea, diarrhea, and myalgia. The main abnormalities in laboratory tests

244 included that lymphocytopenia and increase in levels of CRP, LDH, and D-dimer, while PCT

245 was normal. These findings are consistent with other literature reports.4,5,8,9 The most

246 common comorbidities were hypertension, cardiovascular disease, and diabetes. Chronic 
medRxiv preprint doi: https://doi.org/10.1101/2020.09.26.20202234; this version posted September 28, 2020. The copyright holder for this preprint (which was not certified by peer review) is the author/funder, who has granted medRxiv a license to display the preprint in perpetuity. All rights reserved. No reuse allowed without permission.

247 obstructive pulmonary disease was rare. Both clinical symptoms and laboratory tests indicated

248 that patients with comorbidities had worse course of the disease, with higher proportion of

249 severe or critical disease and poorer prognosis. Patients with comorbidities manifested with

250 more dyspnea, lower lymphocyte count, and higher LDH, compared with those who had no

251 comorbidities. These were manifestations of COVID-19 disease, rather than worsening

252 symptoms of the comorbidities due to infection with SARS-Cov-2. We also found that the

253 proportion of critical type COVID-19 increased with age. Lower lymphocyte count and

254 SpO2were found in a higher proportion of patients with severe or critical type. These findings

255 suggest that healthcare providers should pay particular attention to age, comorbidities,

256 lymphocyte count, and $\mathrm{SpO} 2$ in the diagnosis and treatment of COVID-19. These factors may

257 predict the progression of the patient from moderate to severe or critical type.

258 Early CT findings showed that the lung lesions were mainly bilateral, mainly involved two

259 or more lobes, and were mainly distributed in the peripheral zones of the lung. GGO,

260 consolidation and mixed GGO and consolidation were the most common CT findings, while

261 pleural effusion was rare. This is also consistent with previous literature reports.10 Through

262 statistical analysis of lung CT imaging on different days in the course of the disease, we found

263 the following progression: the early CT finding was GGO (1-7 days); the GGO lesion resolved

264 or gradually evolved into consolidation shadow (1-2 weeks); consolidation resolved(2-3

265 weeks);then, linear opacity or reticular changes developed (4-6 weeks). The whole course took

266 about a month. In the statistical analysis of the correlation between symptom improvement and

267 pulmonary imaging changes in 36 patients, nearly half of the patients (16/36) showed

268 resolution of GGO lesions and aggravation of consolidation lesions when the clinical 
medRxiv preprint doi: https://doi.org/10.1101/2020.09.26.20202234; this version posted September 28, 2020. The copyright holder for this preprint (which was not certified by peer review) is the author/funder, who has granted medRxiv a license to display the preprint in perpetuity. All rights reserved. No reuse allowed without permission.

269

270

271

272

273

274

275

symptoms improved. Histological Lung biopsy specimen showed interstitial mononuclear inflammatory infiltrates (dominated by lymphocytes), diffuse alveolar damage with cellular fibro-myxoid exudate, or hyaline membrane formation.11 This is different from what is seen in bacterial pneumonia. Therefore, the change in extent of GGO lesions can be used to predict the outcome of the disease, while consolidation shadow should not be used as aprognostic factor for the patients' condition.

In this study, all patients had positive nucleic acid tests for pharyngeal swabs. Seven cases had positive nucleic acid test for stool samples, but only six cases had diarrhea. One patient tested positive for urine nucleic acid test, which is a rare report at present, and may suggest that SARS-Cov-2 may cause urinary tract infection.

Most of the patients in this study were treated with antiviral drugs, including lopinavir and tonavir. Currently, there are no research data that show that such drugs have a clear effect on COVID-19. In this study, we found that the lower the lymphocyte count, the more the number of days for nucleic acid test to change from positive to negative. The longer the duration from onset of illness to admission, the longer the duration before improvement of symptoms, and the shorter the duration from onset of illness to admission, the shorter the duration for CT image improvement. Comparing patients in Hubei and Guangxi, we found that patients from Hubei had more severe disease and more days from onset of illness to admission than those from Guangxi. All of these findings suggest that early isolation, early diagnosis, and early initiation of management can contribute to slowing down the progression and spread of COVID-19.

The present study has some limitations. First, due to the limited number of cases, some results need to be further validated with more patients. Second, the effect of antiviral agents 
medRxiv preprint doi: https://doi.org/10.1101/2020.09.26.20202234; this version posted September 28, 2020. The copyright holder for this preprint (which was not certified by peer review) is the author/funder, who has granted medRxiv a license to display the preprint in perpetuity.

All rights reserved. No reuse allowed without permission.

291

292

293

294

295

\section{Disclosure}

\section{Funding}

and corticosteroidson COVID-19 needs further validation. Prospective studies should be performed to get more accurate results. Third, because this was a retrospective analysis, the time of CT imaging and nucleic acid test was not standardized and unified, t may have reduced the accuracy of the result. More cases need to be analyzed to obtain more information.

\section{Conclusions}

In this study, we found that older patients and patients with comorbiditieshad higher proportion of severe or critical type COVID-19. Lymphocyte count and and $\mathrm{SpO} 2$ at admission were associated with disease severity. Early isolation, early diagnosis, and early initiation of management can contribute to slowing down the progression and spread ofCOVID-19. These findings will be helpful for the diagnosis and treatment of COVID-19.

This research received no external funding.

The authors declare no conflicts of interest associated with this manuscript.

\section{Author Contributions}

WZ made substantial contributions to the conception and design of the study; acquisition, analysis, and interpretation of the data; and drafting of the manuscript. XF, JH, CD and DQ made substantial contributions to the conception and design of the study; acquisition, analysis, and interpretation of the data; and critical revision of the manuscript for important intellectual content. $\mathrm{XZ}$ and $\mathrm{JZ}$ also gave final approval of the version to be published and agree to be accountable for all aspects of the work in ensuring that questions related to the 
medRxiv preprint doi: https://doi.org/10.1101/2020.09.26.20202234; this version posted September 28, 2020. The copyright holder for this preprint (which was not certified by peer review) is the author/funder, who has granted medRxiv a license to display the preprint in perpetuity. All rights reserved. No reuse allowed without permission.

312

313

315

316

\section{Acknowledgements}

\section{Ethical approval}

321 This study was approved by the ethics committee associated with the Faculty of Medicine at The First Affiliated

322 Hospital of Guangxi Medical University[2020(KY-E-06).]. Informed consent was done appropriately for subjects.

\section{References}

Organization.

Situation

Report-102.

Available

at:

42f4a18_4.AccessedMay 1, 2020.

2. Huang C, Wang Y, Li X, et al. Clinical features of patients infected with 2019 novel coronavirus in Wuhan,

China. Lancet 2020;395:496. doi: 10.1016/S0140-6736(20)30252-X. 
medRxiv preprint doi: https://doi.org/10.1101/2020.09.26.20202234; this version posted September 28, 2020. The copyright holder for this preprint (which was not certified by peer review) is the author/funder, who has granted medRxiv a license to display the preprint in perpetuity. All rights reserved. No reuse allowed without permission.

334

335

336

337

338

339

340

341

342

343

344

Respir Crit Care Med 2020;201:1380-8.

5.Chen N, Zhou M, Dong X, et al. Epidemiological and clinical characteristics of 99 cases of 2019 novel coronavirus pneumonia in Wuhan, China: a descriptive study. Lancet 2020;395:507-13.doi: 10.1016/S0140-6736(20)30211-7.

6.Rong W, Lingli X, Peng D, Fan H, Song M. Clinical characteristics of 96 hospitalized patients with coronavirus disease 2019.Chin J Respir Crit Care Med 2020;19:144-7.

7. China National Health Commission. Chinese Clinical Guidance for COVID-19 Pneumonia Diagnosis and Treatment (7th edition). Available at: http://kjfy.meetingchina.org/msite/news/show/cn/3337.html. Accessed on April 1, 2020.

8.Bassetti M, Vena A, Giacobbe DR. The novel Chinese coronavirus (2019-nCoV) infections: challenges for fighting the storm. Eur J Clin Invest2020;50:e13209.doi: 10.1111/eci.13209.

9.Holshue ML, Debolt C, Lindquist S, et al. First case of 2019 novel coronavirus in the United States. N Engl J Med2020;382:929-36.doi: 10.1056/NEJMoa2001191.

10.Li B, Li X, Wang Y, et al. Diagnostic value and key features of computed tomography in coronavirus disease 2019.Emerg Microbes Infect2020; 9:787-93.doi: 10.1080/22221751.2020.1750307.

11.Xu Z, Shi L, Wang Y, et al. Pathological findings of COVID-19 associated with acute respiratory distress syndrome. Lancet Respir Med2020;8:420-2.doi: 10.1016/S2213-2600(20)30076-X. 
Table1:Clinical features of study subjectsin different locations

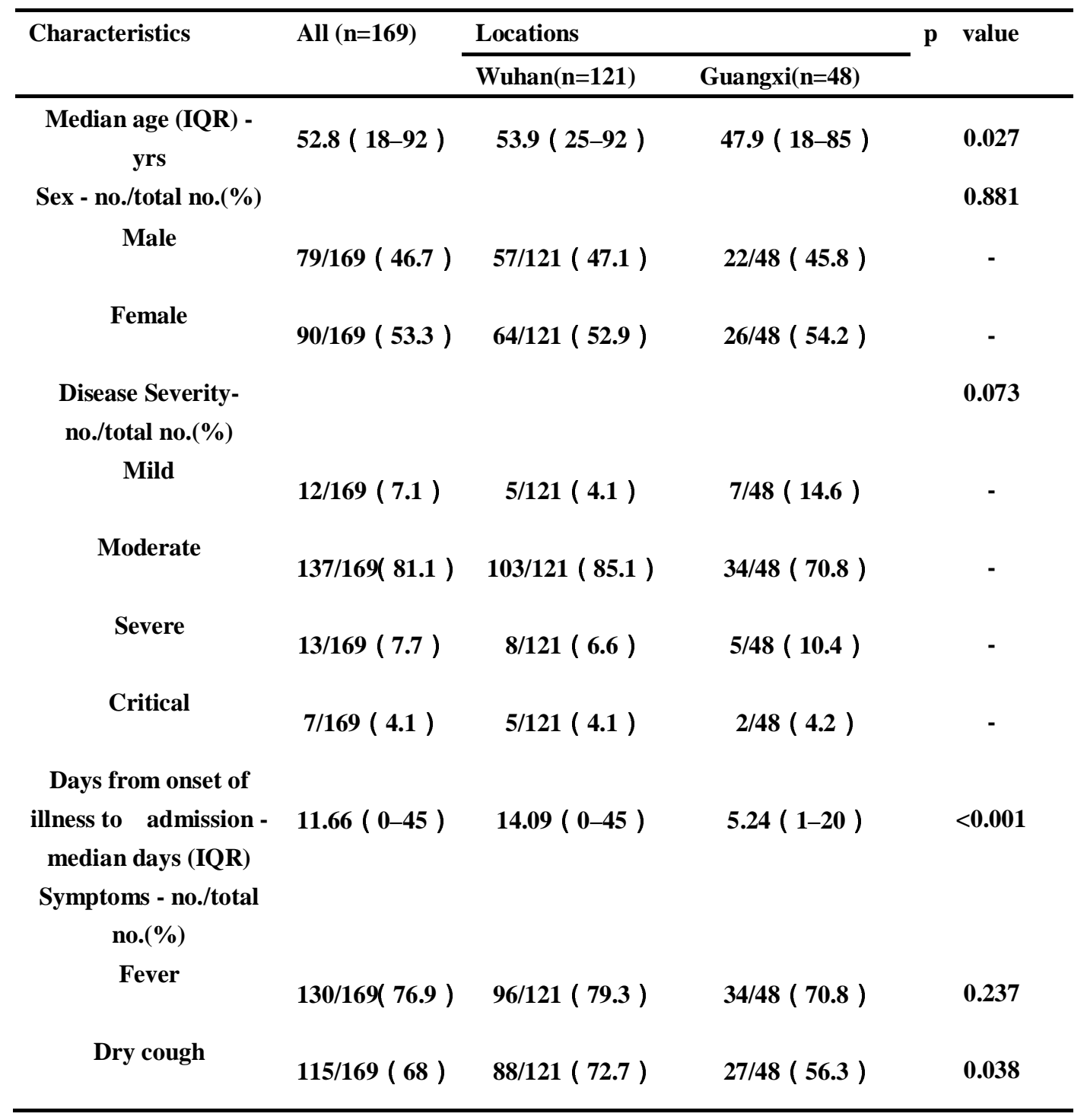




\begin{tabular}{|c|c|c|c|c|}
\hline Sputum production & 46/169 ( 27.4$)$ & $45 / 121(37.5)$ & $1 / 48(2.1)$ & $<0.001$ \\
\hline Shortness of breath & $38 / 169$ ( 22.5 ) & 31/121 ( 25.6 ) & $7 / 48(14.6)$ & 0.121 \\
\hline Myalgia & $15 / 169$ ( 8.9 ) & 14/121 ( 11.6 ) & $1 / 48(2.1)$ & 0.070 \\
\hline Digestive symptoms & 29/169 ( 17.3$)$ & $22 / 121(18.3)$ & $7 / 48(14.6)$ & 0.576 \\
\hline \multicolumn{5}{|l|}{$\begin{array}{l}\text { Comorbidities- } \\
\text { no./total no. (\%) }\end{array}$} \\
\hline Any comorbidity & $52 / 169(30.8)$ & 40/121 ( 33.1$)$ & $12 / 48(25.0)$ & 0.306 \\
\hline Hypertension & $30 / 169$ ( 17.8$)$ & 23/121 ( 19.0$)$ & $7 / 48(14.6)$ & 0.497 \\
\hline $\begin{array}{c}\text { Cardiovascular } \\
\text { disease }\end{array}$ & $14 / 169(8.3)$ & 11/121 ( 9.1$)$ & $3 / 48(6.3)$ & 0.759 \\
\hline Diabetes & $11 / 169(6.5)$ & $10 / 121(8.3)$ & $1 / 48(2.1)$ & 0.183 \\
\hline Malignancy & 1/169 ( 0.6$)$ & 1/121 ( 0.8$)$ & $0 / 48$ ( 0 ) & 1.000 \\
\hline $\begin{array}{c}\text { Cerebrovascular } \\
\text { disease }\end{array}$ & $5 / 169(3.0)$ & $5 / 121(4.1)$ & $0 / 48$ ( 0 ) & 0.323 \\
\hline $\begin{array}{l}\text { COPD or chronic } \\
\text { bronchitis }\end{array}$ & $4 / 169(2.4)$ & $4 / 121(3.3)$ & $0 / 48$ ( 0 ) & 0.579 \\
\hline Others & $10 / 169(5.9)$ & 9/121 ( 7.4$)$ & $1 / 48(2.1)$ & 0.285 \\
\hline \multicolumn{5}{|l|}{$\begin{array}{l}\text { Laboratory findings- } \\
\text { median (IQR) }\end{array}$} \\
\hline $\mathrm{SpO}_{2}=\%$ & $\begin{array}{c}95.73 \\
(70-100)\end{array}$ & $95.72(70-100)$ & $96(87-100)$ & 0.364 \\
\hline Total protein - $\mathrm{g} / \mathrm{L}$ & $\begin{array}{c}68.69 \\
(36.7-98.0)\end{array}$ & 66.68 ( 36.7-98.0) & $73.62(54.7-86.3)$ & $<0.001$ \\
\hline Albumin - g/L & $38.8(18-53.8)$ & $37.78(18-53.8)$ & $41.19(24.6-53.0)$ & 0.004 \\
\hline Globulin - g/L & $\begin{array}{c}29.86 \\
(9.8-54.5)\end{array}$ & $28.87(9.8-47.2)$ & $32.38(23.0-54.5)$ & 0.002 \\
\hline $\begin{array}{c}\text { Total bilirubin - } \\
\qquad \mu \mathrm{mol} / \mathrm{L}\end{array}$ & $\begin{array}{c}12.72 \\
(2.7-62.0)\end{array}$ & $14.13(5.8-49.2)$ & $9.88(2.7-62.0)$ & 0.011 \\
\hline ALT-U/L & 44.62 & $49.98(2.0-547.7)$ & $30.46(18.0-65.2)$ & 0.006 \\
\hline
\end{tabular}




\begin{tabular}{|c|c|c|c|c|}
\hline \multirow{3}{*}{ AST-U/L } & (2.0-574.7) & & & \\
\hline & 42.83 & & & \\
\hline & $(5.0-584.0)$ & $47.79(9.0-584)$ & $29.74(5.0-72.8)$ & 0.007 \\
\hline GGT-U/L & 78.24 ( 7-906 ) & 74.69 ( 7-906 ) & 130.3 ( 9-601 ) & 0.585 \\
\hline \multirow[t]{2}{*}{ Creatinine - $\mu \mathrm{mol} / \mathrm{L}$} & 73.4 & & & \\
\hline & (34.5-359) & 75.88 ( 39-359) & $68.2(34.5-245)$ & 0.276 \\
\hline $\begin{array}{l}\text { White blood cell count } \\
\qquad \times \times 10^{9} / \mathrm{L}\end{array}$ & $7.07(1.01-65)$ & $7.18(1.01-65)$ & $6.77(2.3-19.4)$ & 0.731 \\
\hline $\begin{array}{l}\text { Neutrophilcount - } \\
\times 10^{9} / \mathrm{L}\end{array}$ & $\begin{array}{c}5.12 \\
(0.52-55.6)\end{array}$ & $5.17(0.52-55.6)$ & $5(0.8-17.6)$ & 0.862 \\
\hline $\begin{array}{l}\text { lymphocyte cell count } \\
\qquad \times \times 10^{9} / \mathrm{L}\end{array}$ & $\begin{array}{c}1.24 \\
(0.18-4.11)\end{array}$ & $1.26(0.18-4.11)$ & $1.18(0.20-2.40)$ & 0.454 \\
\hline \multirow[t]{2}{*}{ Hemoglobin - g/L } & 130.51 & & & \\
\hline & $(84-230)$ & $130.39(84-230)$ & $131.13(96-219)$ & 0.873 \\
\hline \multirow[t]{2}{*}{ Platelet count $-\times 10^{9} / \mathrm{L}$} & 222.35 & & & \\
\hline & $(55-564)$ & $219.12(55-538)$ & $238.78(119-564)$ & 0.328 \\
\hline $\begin{array}{c}\text { C-reactive protein - } \\
\mathrm{mg} / \mathrm{L}\end{array}$ & $\begin{array}{c}33.77 \\
(\mathbf{0 . 0 4 - 2 8 5})\end{array}$ & $\begin{array}{c}31.19 \\
(\mathbf{0 . 0 4}-254.35)\end{array}$ & $40.05(0.5-285)$ & 0.316 \\
\hline \multirow[t]{2}{*}{ PCT $-\mu \mathrm{g} / \mathrm{mL}$} & 0.35 & & & \\
\hline & $(0.02-6.02)$ & $0.37(0.02-6.02)$ & $0.29(0.02-2.94)$ & 0.468 \\
\hline \multirow[t]{2}{*}{ LDH - U/L } & 263.16 & & & \\
\hline & ( 120-808) & $281.56(120-808)$ & $227.65(151-610)$ & 0.009 \\
\hline \multirow[t]{2}{*}{ Creatine kinase - U/L } & 107.53 & & & \\
\hline & ( 12-1381) & $110.94(28-1381)$ & $101.81(12-355)$ & 0.745 \\
\hline CK-MB - U/L & $13.91(1-73)$ & $13.02(4-45.7)$ & $15.12(1-73)$ & 0.305 \\
\hline \multirow[t]{2}{*}{ PT-s } & 14.65 & & & \\
\hline & (9.7-100) & $15.43(9.7-100)$ & $13.09(10.5-17)$ & 0.081 \\
\hline D-dimer - $\mu \mathrm{g} / \mathrm{ml}$ & $2.16(0-89)$ & $2.7(0-89)$ & $0.76(0.02-20.58)$ & 0.292 \\
\hline Treatment- no./total & & & & \\
\hline
\end{tabular}


medRxiv preprint doi: https://doi.org/10.1101/2020.09.26.20202234; this version posted September 28, 2020. The copyright holder for this preprint (which was not certified by peer review) is the author/funder, who has granted medRxiv a license to display the preprint in perpetuity.

All rights reserved. No reuse allowed without permission.

no. $(\%)$

Antiviral

91/169( 53.85 )

$73(60.30)$

18 ( 37.50$)$

0.007

Antibiotics

$154 / 169$

(91.10)

108 ( 89.30$)$

$46(95.80)$

0.291

Corticosteroids

$$
\text { 48/169( } 28.40 \text { ) }
$$

$42(34.70)$

$6(12.50)$

0.004

Outcome- no./total no.

0.561

(\%)

Improvement

$165 / 169$

(97.60)

117/121 ( 96.70 )

48/48 ( 100 )

Death

4/169 ( 2.40$)$

4/121 ( 3.30 )

0/48 ( 0 )

364

365

366

367

368

369

370

371

372

373

374

375

376

377

378

379 
medRxiv preprint doi: https://doi.org/10.1101/2020.09.26.20202234; this version posted September 28, 2020. The copyright holder for this preprint (which was not certified by peer review) is the author/funder, who has granted medRxiv a license to display the preprint in perpetuity.

All rights reserved. No reuse allowed without permission.

380

381

382

383

384 
Table2: Clinical features of study subjects according to age group

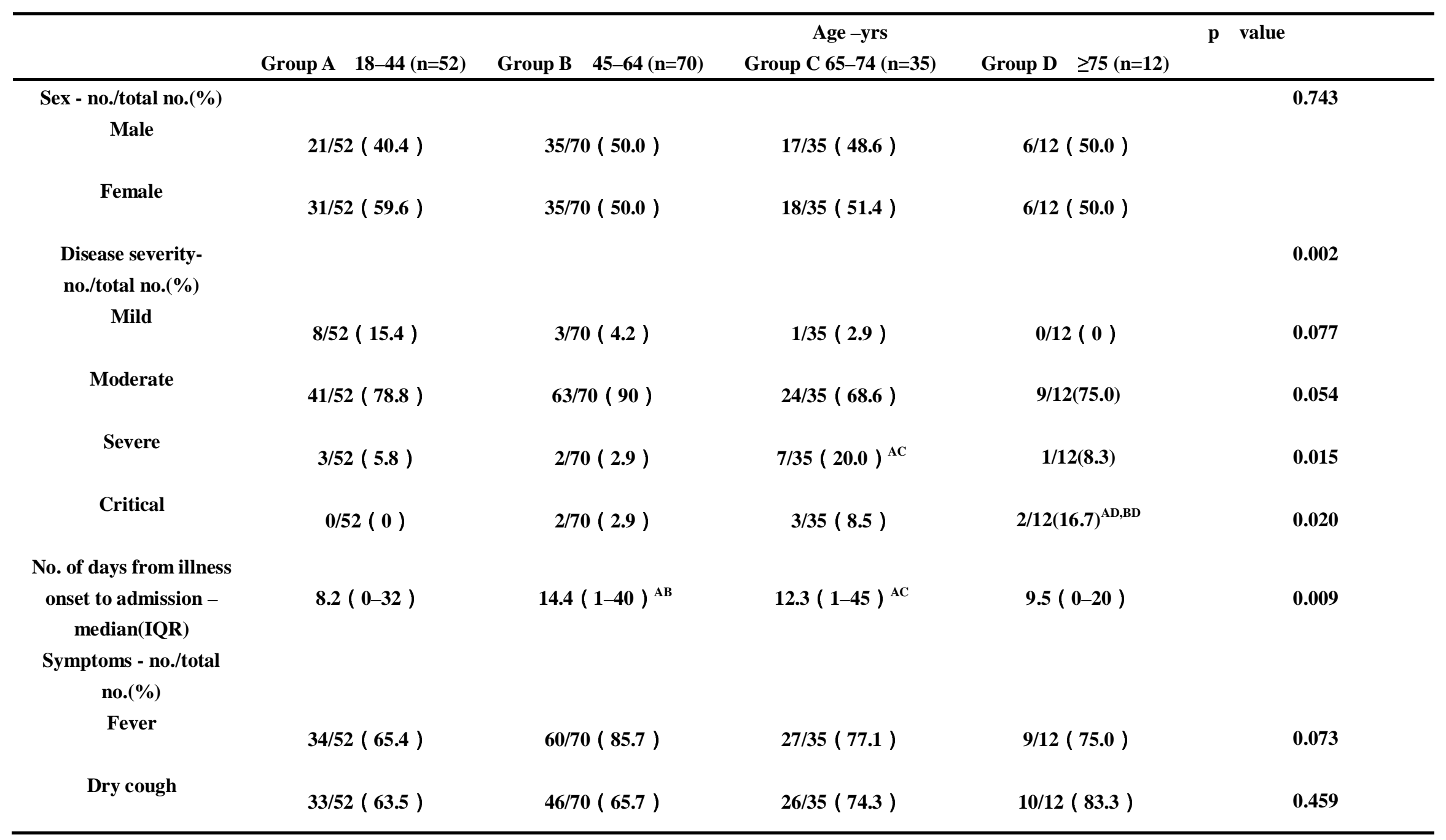




\begin{tabular}{|c|c|c|c|c|c|}
\hline Sputum production & $10 / 52(19.2)$ & $22 / 70(31.9)$ & $11 / 35(31.4)$ & 3/12 ( 25 ) & 0.43 \\
\hline Shortness of breath & $3 / 52(5.8)$ & $14 / 70(20.0)^{A B}$ & $17 / 35(48.6)^{\mathrm{AC}}$ & $4 / 12(33.3)^{A D}$ & $<0.001$ \\
\hline Myalgia & $2 / 52$ ( 3.8$)$ & $8 / 70(22.4)$ & 4/35 (11.4) & $1 / 12(8.3)$ & 0.395 \\
\hline Digestive symptoms & 9/52 ( 17.3$)$ & $11 / 70(15.7)$ & $7 / 35(20)$ & 2/12 ( 16.7$)$ & 0.944 \\
\hline \multicolumn{6}{|l|}{$\begin{array}{c}\text { Comorbidities - no./total } \\
\text { no. }(\%)\end{array}$} \\
\hline Any comorbidity & 6/52 ( 11.5$)$ & $21 / 70(30)$ & $19 / 35(54.3)$ & $6 / 12(50.0)$ & $<0.001$ \\
\hline Hypertension & $3 / 52(5.8)$ & $10 / 70(14.3)$ & $12 / 35(34.3)$ & $5 / 12(41.7)$ & 0.001 \\
\hline Cardiovascular disease & $2 / 52(3.8)$ & 7/70 ( 10.0$)$ & $5 / 35(14.3)$ & $0 / 12(0)$ & 0.257 \\
\hline Diabetes & $0 / 52(0)$ & $2 / 70(2.9)$ & $8 / 35(22.9)$ & $1 / 12(8.3)$ & $<0.001$ \\
\hline Malignancy & $0 / 52(0)$ & $0 / 70(0)$ & 1/35 ( 2.9$)$ & $0 / 12(0)$ & 0.278 \\
\hline Cerebrovascular disease & $0 / 52(0)$ & $0 / 70(0)$ & $1 / 35(2.9)$ & $4 / 12(33.3)$ & $<0.001$ \\
\hline COPD & $0 / 52(0)$ & $0 / 70(0)$ & $3 / 35(8.5)$ & $1 / 12(8.3)$ & 0.006 \\
\hline Others & $2 / 52(3.8)$ & $5 / 70(7.1)$ & $2 / 35(5.7)$ & $1 / 12(8.3)$ & 0.825 \\
\hline $\begin{array}{l}\text { Laboratory findings- } \\
\text { median (IQR) }\end{array}$ & & & & & \\
\hline
\end{tabular}




\begin{tabular}{|c|c|c|c|c|c|}
\hline $\mathrm{SpO}_{2} \%$ & $97.31(93-100)$ & 96.17 ( 70-99 ) & $93.26(76-98)$ & 93.55 ( 80-98 ) & $\mathbf{0 . 0 3 2}$ \\
\hline Total protein - g/L & $73(57-86.3)$ & $68.5(36.7-98)^{A B}$ & $63.5(53.4-82.2)^{\mathrm{AC}, \mathrm{BC}}$ & $65.7(51-81.8)^{\mathrm{AD}}$ & $<0.001$ \\
\hline Albumin - g/L & $43.3(32.6-53)$ & $38.6(18-53.8)$ & $33.3(20-44.5)$ & $36.1(27-44)$ & $<0.001$ \\
\hline Globulin - g/L & $29.7(22-39.7)$ & $29.9(9.8-47.2)$ & $30(19-54.5)$ & $29.5(18-41.8)$ & 0.947 \\
\hline Total bilirubin - $\mu \mathrm{mol} / \mathrm{L}$ & $11.9(2.91-49.2)$ & $11.5(2.8-33)$ & $12.8(2.7-48)$ & $20.5(5.9-62)$ & 0.151 \\
\hline ALT-U/L & $45(7-547.7)$ & $50.4(11-479)$ & $32.3(10-81)$ & $41.5(2-101)$ & 0.626 \\
\hline AST-U/L & $35.1(9-352.7)$ & $49.2(13-584)$ & $38.1(5-157)$ & $51.6(20-109.2)$ & 0.540 \\
\hline GGT-U/L & 93.5 ( 10-906 ) & $82.2(8-527)$ & $72.8(7-601)$ & $44(7-906)$ & 0.766 \\
\hline Creatinine - $\mu \mathrm{mol} / \mathrm{L}$ & $61(34.5-91)$ & $74.2(41-241)$ & $78(46.1-245)$ & $104.5(60-359)$ & 0.001 \\
\hline $\begin{array}{l}\text { White blood cell count - } \\
\qquad \times 10^{9} / \mathrm{L}\end{array}$ & $6.78(2.3-60.9)$ & $7.46(2.34-65)$ & $7.1(1.01-19.4)$ & $5.9(1.92-13.61)$ & 0.893 \\
\hline $\begin{array}{l}\text { Neutrophil count - } \\
\times 10^{9} / \mathrm{L}\end{array}$ & $4.76(0.8-55.6)$ & $5.2(1.12-20.71)$ & $5.62(0.52-17.6)$ & $5.1(1.03-10.66)$ & 0.91 \\
\hline $\begin{array}{l}\text { Lymphocyte count - } \\
\qquad \times 10^{9} / \mathrm{L}\end{array}$ & $1.43(0.43-3.3)$ & $1.31(0.23-4.11)$ & $0.94(0.18-2.2)^{\mathrm{AC}, \mathrm{BC}}$ & $0.85(0.2-2.07)^{\mathrm{AD} . \mathrm{BD}}$ & 0.001 \\
\hline Hemoglobin - g/L & 137.47 ( 102-230 ) & $131.48(100-191)$ & $123.5(84-177)$ & $114.72(87-147)$ & 0.001 \\
\hline Platelet count $-\times 10^{9} / \mathrm{L}$ & $218.5(55-431)$ & $225.73(84-564)$ & $243(100-538)$ & $167.36(85-250)$ & 0.108 \\
\hline
\end{tabular}




\begin{tabular}{|c|c|c|c|c|c|}
\hline $\begin{array}{c}\text { C-reactive protein - } \\
\mathrm{mg} / \mathrm{L}\end{array}$ & $17.76(0.04-78.95)$ & $30.11(0.4-149.68)$ & $46.84(0.4-285)$ & $88.57(1-254.35)$ & 0.006 \\
\hline PCT $-\mu \mathrm{g} / \mathrm{mL}$ & $0.21(0.02-0.67)$ & $0.34(0.04-2.57)$ & $0.49(0.03-6.02)$ & $0.56(0.08-2.05)$ & 0.017 \\
\hline LDH - U/L & $212.86(120-681)$ & $275.74(123-686)^{\mathrm{AB}}$ & $282.2(175-544)^{\mathrm{AC}}$ & $369.09(177-808)^{\mathrm{AD}}$ & $<0.001$ \\
\hline Creatinekinase - U/L & $117.42(31.4-1381)$ & 101.87 ( 28-355) & $88.87(12-216)$ & $120.6(43-600)$ & 0.891 \\
\hline CK-MB - U/L & $14.09(5-68)$ & $12.75(4-45.7)$ & $17.34(6-73)$ & $16.52(5-32.26)$ & 0.405 \\
\hline PT-s & $0.24(0.01-1.23)$ & $0.88(0-7.8)$ & $4,23(0.02-80)$ & $10.66(0.18-89)^{A D, B D, C D}$ & $<0.001$ \\
\hline D-dimer - $\mu \mathrm{g} / \mathrm{ml}$ & $13.16(9.7-15.8)$ & 13.37 ( 9.7-29.3) & $15.57(10.9-76)$ & $21.87(12.6-100)^{\text {AD.BD }}$ & 0.001 \\
\hline \multicolumn{6}{|l|}{$\begin{array}{l}\text { Immunology - median } \\
(\text { IQR) }\end{array}$} \\
\hline IgG- g/L & $11.53(7.84-15.16)$ & $13.39(7.42-20.81)$ & $12.66(7.96-16.69)$ & 12.75 ( 7.24-19.18) & 0.647 \\
\hline $\operatorname{IgA-g/L}$ & $2.15(1.32-3.44)$ & $2.63(1.37-5.09)$ & $2.07(1.47-3.34)$ & $2.65(2.38-4.71)$ & 0.26 \\
\hline IgM- g/L & $1.42(0.64-2.29)$ & $1.53(0.64-3.15)$ & $1.37(0.82-2.55)$ & $1.18(0.38-2.49)$ & 0.662 \\
\hline IgE- g/L & 74.77 ( 2.4-480.1) & $124.38(1.3-1100)$ & $32.85(0.8-76.1)$ & 154.15 ( 2.8-1008) & 0.717 \\
\hline IL-6- pg/mL & $1.69(15-2.84)$ & $6.76(1.5-42.53)$ & $33.57(1.5-223.81)$ & $71.34(2.89-252.7)$ & 0.007 \\
\hline C3- g/L & $0.94(0.8-1.3)$ & $0.94(0.6-1.3)$ & $0.85(0.8-1)$ & $0.94(0.6-1.4)$ & 0.701 \\
\hline
\end{tabular}




\begin{tabular}{|c|c|c|c|c|c|}
\hline C4- g/L & $0.199(0.1-0.4)$ & $0.18(0.1-0.3)$ & $0.18(0.1-0.2)$ & $0.22(0.1-0.4)$ & 0.61 \\
\hline $\mathrm{CD3}+$ cell count - cell $/ \mu \mathrm{l}$ & 1057.83 ( 243-1736) & 785.66(377-1357) & 577.28(142-1310) & - & 0.015 \\
\hline CD4+ cell count - cell/ $\mu \mathrm{l}$ & 666.77(79-1320) & $520.5(207-1000)$ & 402.57(79-883) & - & 0.081 \\
\hline CD8+ cell count - cell $/ \mu \mathrm{l}$ & 391.05(107-892) & $265.16(75-548)$ & $174.71(58-427)$ & - & 0.011 \\
\hline $\begin{array}{c}\text { CD4+ cell percentage } \\
-\%\end{array}$ & - & $45.87(42.32-50.93)$ & 39.85 ( $10.83-59.3)$ & 31.23 & 0.546 \\
\hline $\begin{array}{c}\text { CD8+ cell percentage } \\
-\%\end{array}$ & - & $24.77(22.08-28.67)$ & $26.18(14.67-46.04)$ & 15.54 & 0.436 \\
\hline $\begin{array}{c}\text { CD3+ cell percentage } \\
-\%\end{array}$ & - & $72.84(70.68-74.79)$ & $68.87(58.64-86.66)$ & 47.77 & 0.195 \\
\hline NK cell percentage - \% & - & $5.18(3.54-6.47)$ & 11.71 ( 2.69-27.59 ) & 7.64 & 0.346 \\
\hline \multicolumn{6}{|l|}{$\begin{array}{c}\text { Number of lung lobes } \\
\text { involved - no./total } \\
\text { no. }(\%)\end{array}$} \\
\hline 5 & $12 / 45(26.7)$ & $29 / 48(60.4)$ & $16 / 25(64.0)$ & $5 / 10(50.0)$ & 0.003 \\
\hline 4 & $2 / 45(4.5)$ & $7 / 48(14.6)$ & $2 / 25(8.0)$ & $0 / 10(0)$ & 0.336 \\
\hline 3 & $3 / 45(6.7)$ & $4 / 48(8.3)$ & $4 / 25(16.0)$ & $4 / 10(4.0)$ & 0.032 \\
\hline 2 & $11 / 45(24.4)$ & $4 / 48(8.3)$ & $2 / 25(8.0)$ & $0 / 10(0)$ & 0.073 \\
\hline 1 & $11 / 45(24.4)$ & $2 / 48(4.2)$ & $0 / 25(0)$ & $1 / 10(10.0)$ & 0.003 \\
\hline
\end{tabular}




\begin{tabular}{|c|c|c|c|c|c|}
\hline $\mathbf{0}$ & $6 / 45(13.3)$ & $2 / 48(4.2)$ & $1 / 25(4.0)$ & $0 / 10(0)$ & 0.343 \\
\hline \multicolumn{6}{|l|}{$\begin{array}{c}\text { Treatment - no./total } \\
\text { no. }(\%)\end{array}$} \\
\hline Antiviral & $21 / 52(40.4)$ & $39 / 70$ ( 55.7 ) & 25/35 ( 71.4$)$ & 6/12 ( 50.0$)$ & 0.047 \\
\hline Antibiotics & 48/52 (92.3) & $66 / 70(94.3)$ & $32 / 35$ ( 91.4 ) & 8/12 ( 66.7$)$ & 0.001 \\
\hline Corticosteroids & $6 / 52(11.5)$ & $19 / 70(27.1)$ & $18 / 35(51.4)$ & $0 / 12(0)$ & 0.001 \\
\hline $\begin{array}{c}\text { Prognosis - no./total } \\
\text { no. }(\%)\end{array}$ & & & & & 0.24 \\
\hline Death & $0 / 52(0)$ & $2 / 70(2.9)$ & $1 / 35(2.9)$ & $1 / 12(8.3)$ & \\
\hline improve & $52 / 52(100.0)$ & 68/70 ( 97.1$)$ & $34 / 35$ ( 97.1$)$ & 11/12 ( 91.7 ) & \\
\hline
\end{tabular}

IQR=interquartile range, COPD=chronic obstructive pulmonary disease, ALT=alanine transaminase, AST=aspartate aminotransferase, GGT=gamma glutamyl transferase, PCT=procalcitonin, LDH=lactate dehydrogenase, CK-MB=creatine kinase-MB，PT=prothrombin time，Ig=immunoglobulin，IL=interleukin, $\mathrm{C3}=$ complement 3, $\mathrm{C} 4=$ complement $4, \mathrm{CD}=$ cluster of differentiation, $\mathrm{NK}=$ natural killer

Comparison between groups $(\mathrm{P}<0.05): \mathrm{AB}=\mathrm{A}$ compared with $\mathrm{B}, \mathrm{AC}=\mathrm{A}$ compared with $\mathrm{C}, \mathrm{AD}=\mathrm{A}$ compared with $\mathrm{D}, \mathrm{BC}=\mathrm{B}$ compared with $\mathrm{C}, \mathrm{BD}=\mathrm{B}$ compared with $\mathrm{D}, \mathrm{CD}=\mathrm{C}$ compared with $\mathrm{D}$. 
medRxiv preprint doi: https://doi.org/10.1101/2020.09.26.20202234; this version posted September 28, 2020. The copyright holder for this preprint (which was not certified by peer review) is the author/funder, who has granted medRxiv a license to display the preprint in perpetuity. All rights reserved. No reuse allowed without permission.

Table 3. Features of study subjects based on presence of comorbidities

Have comorbidities

$(\mathrm{N}=\mathbf{5 2})$

Disease severity-

no./total no. $(\%)$

Mild

Moderate

Severe

Critical

Sex - no./total no. (\%)

Male

Female

Age inyrs- median

(IQR)

Days from onset of

illness to confirmation

of diagnosis -

median (IQR)

Symptoms - no./total

no. $(\%)$

Fever

Dry cough

Sputum production

Shortness of breath

Digestive symptoms

$$
\text { Myalgia }
$$

Laboratory

findings-median (IQR)

1/52 ( 1.9 )

40/52 ( 76.9 )

$5 / 52(9.6)$

6/52 ( 11.6 )

27/52 ( 51.9 )

25/52 ( 48.1 )

59.88 ( 25-86 )

11.18 ( 0-40)

43/52 ( 82.7 )

$39 / 52$ ( 75.0 )

17/52 ( 33.3 )

$19 / 52$ ( 36.5 )

6/52 ( 11.5 )

9/52 ( 17.6 )
Have no comorbidities

p value
$11.86(0-45)$

0.691

29/117 ( 24.8 )

19/117 ( 16.2 )

9/117 ( 7.7 )

0.604

20/117 ( 17.1 )

0.931

$\mathrm{SpO}_{2-} \%$

94.4 ( 70-99)

96.3 ( 72-100 )

0.121 


\begin{tabular}{|c|c|c|c|}
\hline Total protein - g/L & $65.66(39-84)$ & 70.06 ( 36.7-98 ) & 0.004 \\
\hline Albumin - g/L & $36.34(18-53)$ & $39.9(20-53.8)$ & 0.002 \\
\hline Globulin - g/L & $29.28(18-47.2)$ & $30.12(9.8-54.5)$ & 0.458 \\
\hline $\begin{array}{c}\text { Total bilirubin - } \\
\mu \mathrm{mol} / \mathrm{L}\end{array}$ & $16.65(4.3-62)$ & $10.91(2.7-49.2)$ & 0.006 \\
\hline ALT-U/L & $33.96(2-120)$ & $49.32(10-574.7)$ & 0.046 \\
\hline AST-U/L & $38.94(5-207)$ & $44.54(9-584)$ & 0.476 \\
\hline GGT-U/L & 71.33 ( $10-601)$ & $81.99(7-906)$ & 0.706 \\
\hline Creatinine - $\mu \mathrm{mol} / \mathrm{L}$ & 81.69 ( 43-359) & $69.45(34.5-241)$ & 0.177 \\
\hline $\begin{array}{l}\text { White blood cell count } \\
\qquad \times \times 10^{9} / \mathrm{L}\end{array}$ & $7.74(1.01-65)$ & $6.77(1.92-60.9)$ & 0.404 \\
\hline $\begin{array}{c}\text { Neutrophil count - } \\
\times 10^{9} / \mathrm{L}\end{array}$ & $5.44(0.52-20.71)$ & $4.96(0.8-55.6)$ & 0.646 \\
\hline $\begin{array}{c}\text { Lymphocyte count - } \\
\times 10^{9} / \mathrm{L}\end{array}$ & $1.07(0.18-2.66)$ & $1.31(0.26-4.11)$ & $\mathbf{0 . 0 3 2}$ \\
\hline Hemoglobin - g/L & $127.95(84-191)$ & $131.57(100-230)$ & 0.331 \\
\hline Platelet count $-\times 10^{9} / \mathrm{L}$ & $213.34(85-392)$ & 226.73 ( $55-564)$ & 0.292 \\
\hline $\begin{array}{c}\text { C-reactive protein - } \\
\text { mg/L }\end{array}$ & $49.72(0.3-254.35)$ & $27.22(0.04-285)$ & 0.026 \\
\hline PCT $-\mu \mathrm{g} / \mathrm{mL}$ & $0.53(0.02-6.02)$ & $0.27(0.02-1.74)$ & 0.091 \\
\hline ESR - mm/h & $44.67(20-97.3)$ & $37.62(9-119)$ & 0.175 \\
\hline LDH - U/L & $327.21(123-808)$ & $235.51(120-681)$ & 0.002 \\
\hline Creatinekinase - U/L & $106.45(12-600)$ & $107.91(28-1381)$ & 0.961 \\
\hline CK-MB - U/L & $16.37(5-73)$ & $12.68(1-45.7)$ & 0.181 \\
\hline D-dimer $-\mu \mathrm{g} / \mathrm{ml}$ & $3.33(0-80)$ & $0.71(0.01-8.00)$ & 0.175 \\
\hline PT-s & $18.18(10.9-100)$ & $13.22(9.7-17.4)$ & 0.101 \\
\hline \multicolumn{3}{|l|}{ Immunological } & \\
\hline
\end{tabular}




\begin{tabular}{|c|c|c|c|}
\hline IgG- g/L & $2.32(1.37-3.54)$ & $2.46(1.32-5.09)$ & 0.625 \\
\hline $\operatorname{IgA}-\mathrm{g} / \mathrm{L}$ & $1.43(0.46-2.98)$ & $1.37(0.38-3.15)$ & 0.785 \\
\hline IgM- g/L & $120.19(0.8-1100)$ & 99.05 ( $1.3-1008)$ & 0.770 \\
\hline IgE- g/L & $11.5(7.24-16.88)$ & $13.03(7.42-20.81)$ & 0.229 \\
\hline C3- g/L & $0.91(0.6-1.2)$ & $0.93(0.6-1.4)$ & 0.719 \\
\hline C4- g/L & $0.18(0.1-0.3)$ & $0.2(0.1-0.4)$ & 0.433 \\
\hline IL-6- pg/mL & $17.67(1.5-124.8)$ & $23.42(0-252.7)$ & 0.773 \\
\hline $\begin{array}{c}\text { CD3+ cell count - } \\
\text { cell } / \mu \mathrm{l}\end{array}$ & $65.6(58.64-75.45)$ & 69.59 ( 47.77-86.66 ) & 0.487 \\
\hline $\begin{array}{c}\text { CD4+ cell count - } \\
\text { cell } / \mu \mathrm{l}\end{array}$ & $12.48(2.69-27.59)$ & $8.9(3.54-18.76)$ & 0.379 \\
\hline $\begin{array}{c}\text { CD8+ cell counts - } \\
\text { cell } / \mu l\end{array}$ & $14.99(1.8-37.85)$ & $17.61(3.3-37.33)$ & 0.673 \\
\hline $\begin{array}{c}\text { CD4+ cell percentage } \\
-\%\end{array}$ & $36.61(10.83-59.3)$ & $42.41(31.23-55)$ & 0.376 \\
\hline $\begin{array}{c}\text { CD8+ cell percentage } \\
-\%\end{array}$ & 26.85 ( $14.67-46.04)$ & $28.8(15.54-73.05)$ & 0.816 \\
\hline $\begin{array}{c}\text { Days before negative } \\
\text { nucleic acid } \\
\text { test-median (IQR) }\end{array}$ & $8.18(2-30)$ & $6.16(1-18)$ & 0.092 \\
\hline $\begin{array}{l}\text { Treatment - no./total } \\
\text { no. }(\%)\end{array}$ & & & \\
\hline Antibiotics & $33 / 52(63.50)$ & 58/117 ( 49.6$)$ & 0.095 \\
\hline Antiviral & $49 / 52(94.2)$ & 105/117 ( 89.7 ) & $\mathbf{0 . 5 5 8}$ \\
\hline Corticosteroids & $16 / 52(30.8)$ & $32 / 117$ ( 27.4$)$ & 0.649 \\
\hline $\begin{array}{l}\text { Outcome - no./total no. } \\
(\%)\end{array}$ & & & 0.008 \\
\hline Death & $4 / 52(7.7)$ & 0/117 ( 0 ) & \\
\hline Improvement & $48 / 52(92.3)$ & $117 / 117(100)$ & \\
\hline
\end{tabular}


402 Table 4:Relationship between age and disease severity ( $\mathrm{N}=169$ )

\begin{tabular}{ccccc}
\hline Variable & B & Wald $\boldsymbol{\chi}^{2}$ & P & 95\%CI \\
\hline Q1 & -4.604 & 32.983 & 0.000 & $(-6.175 \sim-3.033)$ \\
Q2 & 0.512 & 0.586 & 0.444 & $(-0.799 \sim 1.823)$ \\
Q3 & 1.770 & 6.063 & 0.014 & $(0.361 \sim 3.180)$
\end{tabular}

Age group

(control: group 5)

$\begin{array}{lllll}1 & -2.675 & 8.098 & 0.004 & (-4.518 \sim-0.883) \\ 2 & -2.382 & 8.146 & 0.004 & (-4.017 \sim-0.746) \\ 3 & -1.768 & 5.022 & 0.025 & (-3.314 \sim-0.222) \\ 4 & -0.628 & 0.691 & 0.406 & (-2.110 \sim 0.853)\end{array}$

$\mathrm{Q} 1=$ Mild disease, $\mathrm{Q} 2=$ Moderate disease, $\mathrm{Q} 3=$ Severe disease, $\mathrm{Q} 4=$ Critical disease

\begin{tabular}{ccccc}
\hline Variable & Univariable analysis & \multicolumn{3}{c}{ Multivariable analysis } \\
& $\mathbf{P}$ & $\mathbf{P}$ & OR & $\mathbf{9 5 \%}$ CI \\
\hline $\mathrm{SpO}_{2}(\%)$ & 0.000 & 0.000 & 0.693 & $(0.572-0.839)$ \\
$\mathrm{Age}($ Year$)$ & 0.003 & 0.482 & - & - \\
Lymphocytes $\left(\times 10^{9} / \mathrm{L}\right)$ & 0.000 & 0.047 & 0.176 & $(0.032-0.976)$ \\
CRP rise(No) & 0.003 & 0.212 & - & - \\
LDH rise(No) & 0.002 & 0.974 & - & - \\
Administration of & 0.000 & 0.505 & - & - \\
corticosteroids & & & & - \\
Days from onset of & 0.049 & 0.070 & - &
\end{tabular}


medRxiv preprint doi: https://doi.org/10.1101/2020.09.26.20202234; this version posted September 28, 2020. The copyright holder for this preprint (which was not certified by peer review) is the author/funder, who has granted medRxiv a license to display the preprint in perpetuity. All rights reserved. No reuse allowed without permission.

$408 \mathrm{LDH}=$ lactate dehydrogenase; $\mathrm{CRP}=\mathrm{C}$-reactive protein; $\mathrm{OR}=$ odds ratio; $95 \% \mathrm{CI}=95 \%$ confidence interval

409

410

diagnosis time

$\begin{array}{ccccc}\text { Underlying disease(No) } & 0.043 & 0.185 & - & \\ \text { Albumin }(\mathrm{g} / \mathrm{L}) & 0.002 & - & - & - \\ \text { D-dimer }(\mu \mathrm{g} / \mathrm{ml}) & 0.019 & 0.307 & 1.056 & (0.951-1.171) \\ \text { Dyspnea(No) } & 0.000 & 0.270 & - & - \\ \text { Cough }(\mathrm{No}) & 0.032 & - & - & -\end{array}$

411

412

413

414

415

416

417

418

419 
Table6:Chest CT findings of study subjects on different days*

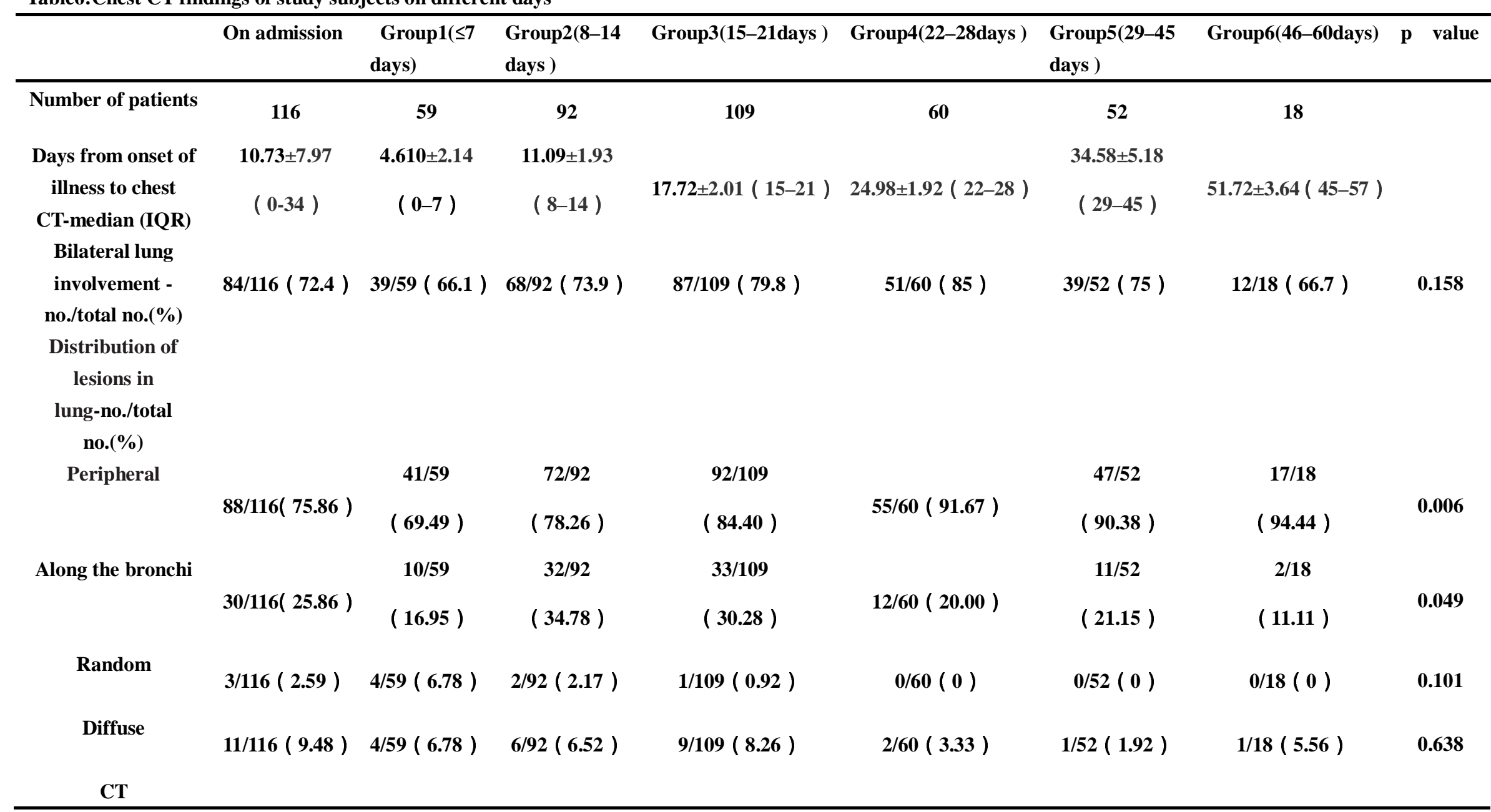




\begin{tabular}{|c|c|c|c|c|c|c|c|c|}
\hline \multicolumn{9}{|l|}{$\begin{array}{c}\text { findings-no./total } \\
\text { no. }(\%)\end{array}$} \\
\hline $\begin{array}{c}\text { Ground-glass } \\
\text { opacity }\end{array}$ & 64/116(55.2) & 48/59(81.4) & 48/92(52.2) & 41/109(37.6) & $17 / 60(28.3)$ & 19/52(36.5) & 8/18(44.4) & $0.001 \#$ \\
\hline Consolidation & 77/116(66.4) & 30/59(50.9) & 72/92(78.3) & 80/109(73.4) & $37 / 60(61.7)$ & 33/55(63.6) & 14/18(77.8) & 0.004@ \\
\hline $\begin{array}{l}\text { Ground-glass } \\
\text { opacity with } \\
\text { consolidation }\end{array}$ & 39/116(33.6) & 16/59(27.1) & 31/92(33.7) & 34/109(31.2) & $12 / 60(20.0)$ & $16 / 55(29.1)$ & 6/18(33.3) & 0.337 \\
\hline Linear opacity & 64/116(55.2) & 20/59(33.9) & 53/92(57.6) & 91/109(83.5) & $56 / 60(93.3)$ & $51 / 52(98.1)$ & 18/18(100) & 0.001 \\
\hline Reticular change & $15 / 116(12.93)$ & 4/59(6.78) & $5 / 92(5.43)$ & 18/109 ( 16.51$)$ & $13 / 60(21.67)$ & 13/52 ( 25.00$)$ & 7/18 ( 38.89 ) & $0.001 ¥$ \\
\hline Pleural thickening & 6/116 ( 5.17$)$ & $0 / 59(0)$ & 3/92 ( 3.26$)$ & 9/109 ( 8.26$)$ & 7/60 ( 11.67$)$ & 9/52 (17.31) & 3/18 ( 16.67$)$ & 0.001 \\
\hline Pleural effusion & 2/116 ( 1.72$)$ & 1/59 ( 1.69$)$ & $0 / 92(0)$ & $2 / 109(1.83)$ & 1/60 ( 1.67$)$ & 1/52 (1.92) & 0/18 ( 0$)$ & 0.753 \\
\hline Vascular thickening & & $12 / 59$ & $28 / 92$ & $47 / 109$ & & $32 / 52$ & $6 / 18$ & \\
\hline & $40 / 116(34.48)$ & ( 20.34$)$ & ( 30.43$)$ & ( 43.12$)$ & $25 / 60(41.67)$ & ( 61.54$)$ & ( 33.33$)$ & 0.001 \\
\hline \multicolumn{9}{|l|}{ Number of lung } \\
\hline \multicolumn{9}{|l|}{$\begin{array}{l}\text { lobes } \\
\text { involved-no./total }\end{array}$} \\
\hline \multicolumn{9}{|l|}{ no. $(\%)$} \\
\hline & & 20/59 & $43 / 92$ & $58 / 109$ & & $28 / 52$ & $12 / 18$ & \\
\hline 5 & $56 / 116(48.28)$ & ( 33.90$)$ & (46.74) & ( 53.21$)$ & $33 / 60(55.00)$ & ( 53.85) & (66.67) & 0.079 \\
\hline
\end{tabular}




\begin{tabular}{|c|c|c|c|c|c|c|c|c|}
\hline \multirow[b]{2}{*}{4} & \multirow[b]{2}{*}{$10 / 116(8.662)$} & \multirow{2}{*}{$\begin{array}{c}6 / 59 \\
(10.17)\end{array}$} & \multirow{2}{*}{$\begin{array}{c}7 / 92 \\
(7.61)\end{array}$} & \multirow{2}{*}{$\begin{array}{c}14 / 109 \\
(12.84)\end{array}$} & \multicolumn{3}{|c|}{$7 / 52$} & \multirow[b]{2}{*}{0.530} \\
\hline & & & & & $6 / 60(10.00)$ & ( 13.46$)$ & $0 / 18(0)$ & \\
\hline \multirow[b]{2}{*}{3} & \multirow[b]{2}{*}{ 16/116( 13.79$)$} & $10 / 59$ & $11 / 92$ & 9/109 & $4 / 60$ & $11 / 52$ & $6 / 18$ & \multirow[b]{2}{*}{0.011} \\
\hline & & ( 16.95$)$ & ( 11.96$)$ & $(8.26)$ & ( 6.67 ) & ( 21.15$)$ & ( 33.33$)$ & \\
\hline \multirow[b]{2}{*}{2} & \multirow[b]{2}{*}{ 17/116( 14.66$)$} & $12 / 59$ & $20 / 92$ & $18 / 109$ & & $4 / 52$ & \multirow[b]{2}{*}{$0 / 18(0)$} & \multirow[b]{2}{*}{0.100} \\
\hline & & $(20.34)$ & $(21.74)$ & ( 16.51$)$ & $12 / 60(20.00)$ & ( 7.69$)$ & & \\
\hline \multirow[b]{2}{*}{1} & \multirow[b]{2}{*}{ 17/116( 14.66$)$} & 11/59 & $11 / 92$ & $10 / 109$ & $5 / 60$ & $2 / 52$ & \multirow[b]{2}{*}{$0 / 18(0)$} & \multirow[b]{2}{*}{0.083} \\
\hline & & ( 18.64$)$ & ( 11.96$)$ & (9.17) & (8.33) & ( 3.85 ) & & \\
\hline
\end{tabular}

\footnotetext{
* Days from onset of illness to chest CT examination

CT=computed tomography, IQR=interquartile range

\#: Group1 compared to other groups; Group2 compared to Group3 and Group4; $\mathbf{p}<0.05$

@: Group1 compared toGroup2, Group3, and Group4; Group2 compared toGroup5; p<0.05

¥ : Group1 compared to other groups; Group2 compared to other groups; $\mathbf{p}<0.05$
} 
medRxiv preprint doi: https://doi.org/10.1101/2020.09.26.20202234; this version posted September 28, 2020. The copyright holder for this preprint (which was not certified by peer review) is the author/funder, who has granted medRxiv a license to display the preprint in perpetuity. All rights reserved. No reuse allowed without permission.

Table 7:Univariable and multivariable analysis of factors associated with the time it takes for nucleic acid test to turn negative $(\mathrm{N}=79)$

\begin{tabular}{|c|c|c|c|c|}
\hline \multirow[t]{2}{*}{ Variable } & \multirow{2}{*}{$\begin{array}{c}\text { Univariable analysis } \\
\text { P }\end{array}$} & \multicolumn{3}{|c|}{ Multivariable analysis } \\
\hline & & $\mathbf{P}$ & B & $95 \% \mathrm{CI}$ \\
\hline Sex(Male) & 0.079 & - & - & - \\
\hline Age(Year) & 0.278 & - & - & - \\
\hline Lymphocytes $\left(\times 10^{9} / \mathrm{L}\right)$ & 0.005 & 0.014 & -2.974 & $(-5.327 \sim-0.620)$ \\
\hline $\mathrm{CRP}(\mathrm{mg} / \mathrm{L})$ & 0.021 & 0.954 & 0.001 & $(-0.022 \sim 0.024)$ \\
\hline $\mathrm{LDH}(\mathrm{U} / \mathrm{L})$ & 0.005 & 0.730 & 0.003 & $(-0.012 \sim 0.017)$ \\
\hline Corticosteroids & 0.005 & 0.137 & -1.710 & $(-3.978 \sim 0.557)$ \\
\hline Antibiotics & 0.024 & 0.154 & -1.563 & $(-3.723 \sim 0.598)$ \\
\hline $\begin{array}{l}\text { LDH=lactate dehydrog } \\
\text { confidence interval }\end{array}$ & ; $C R P=C$-reactive protein; & $B=$ Regre & coet & nts; $95 \% \mathrm{CI}=95 \%$ \\
\hline
\end{tabular}

Table 8:Univariable and multivariable analysis of factors associated with the time it takes for symptoms to improve ( $\mathrm{N}=53$ )

\begin{tabular}{ccccc}
\hline Variable & Univariable analysis & \multicolumn{3}{c}{ Multivariable analysis } \\
& P & P & B & $\mathbf{9 5 \%}$ CI \\
\hline Sex(Male) & 0.724 & - & - & - \\
Age $($ Year $)$ & 0.052 & 0.095 & 0.146 & $(-0.025 \sim 0.319)$ \\
Lymphocytes $\left(\times 10^{9} / \mathrm{L}\right)$ & 0.029 & 0.440 & 1.713 & $(-2.708 \sim 6.134)$ \\
CRP $(\mathrm{mg} / \mathrm{L})$ & 0.993 & - & - & - \\
LDH $(\mu / \mathrm{L})$ & 0.792 & - & - & - \\
Administration of & 0.323 & - & - & - \\
corticosteroid & & & & \\
Timefrom onset of & & & & \\
illness to confirmation of & 0.000 & 0.001 & 0.527 & $(0.219 \sim 0.835)$ \\
diagnosis (days) & & & & \\
\hline
\end{tabular}

LDH=lactate dehydrogenase; CRP=C-reactive protein; $\mathrm{B}=$ Regression coefficients; $95 \% \mathrm{CI}=95 \%$ confidence interval 
Table 9:Univariable and multivariable analysis of factors associated with chest CT improvement( $\mathrm{N}=62$ )

\begin{tabular}{|c|c|c|c|c|}
\hline \multirow[t]{2}{*}{ Variable } & \multirow{2}{*}{$\begin{array}{c}\text { Univariable analysis } \\
\text { P }\end{array}$} & \multicolumn{3}{|c|}{ Multivariable analysis } \\
\hline & & $\mathbf{P}$ & HR & $95 \% \mathrm{CI}$ \\
\hline Sex(Male) & 0.023 & 0.109 & 0.608 & $(0.331-1.117)$ \\
\hline Age(Year) & 0.195 & - & - & - \\
\hline Lymphocytes $\left(\times 10^{9} / \mathrm{L}\right)$ & 0.088 & 0.278 & 1.374 & $(0.774-2.440)$ \\
\hline $\mathrm{CRP}(\mathrm{mg} / \mathrm{L})$ & 0.561 & - & - & - \\
\hline LDH(U/L) & 0.899 & - & - & - \\
\hline $\begin{array}{l}\text { Administration of } \\
\text { corticosteroid }\end{array}$ & 0.540 & - & - & - \\
\hline $\begin{array}{l}\text { Time from onset of } \\
\text { illness to confirmation of } \\
\text { diagnosis (days) }\end{array}$ & 0.075 & 0.013 & 1.019 & (1.019-1.168) \\
\hline Disease severity & 0.045 & 0.061 & - & - \\
\hline $\begin{array}{l}\text { Moderate(compared to } \\
\text { mild mild) }\end{array}$ & - & 0.008 & 0.261 & $(0.097-0.704)$ \\
\hline $\begin{array}{l}\text { Severe(compared to } \\
\text { mild mild) }\end{array}$ & - & 0.057 & 0.192 & $(0.035-1.049)$ \\
\hline $\begin{array}{l}\text { Critical(compared to } \\
\text { mild mild) }\end{array}$ & - & 0.971 & 0 & 0 \\
\hline $\begin{array}{l}\text { Time of onset to nucleic } \\
\text { acid positive time(days) }\end{array}$ & 0.059 & 0.853 & 1.009 & $(0.918-1.110)$ \\
\hline
\end{tabular}

$\mathrm{CT}=$ computed tomography, $\mathrm{LDH}=$ lactate dehydrogenase, $\mathrm{CRP}=\mathrm{C}$-reactive protein, $\mathrm{HR}=$ hazard ratio, $95 \% \mathrm{CI}=95 \%$ confidence interval

\section{Figurelegends}

Figure 1 : Computed tomography findings in the lungs on different days in the course of the disease in a patient with severe disease.(a) 4 days from onset of illness.(b) 8 days from illness onset ( patient's clinical symptoms began to improve ) .(c)13 days from onset of illness. (d)18 days from onset of illness. (e)23 days from onset of illness onset.

Figure 2: Computed tomography findings in the lungs on different days in the course 
of the disease in a patient with moderate disease. (a)5 days from onset of illness. (b)10 days from onset of illness (patient's clinical symptoms began to improve). (c)15 days from onset of illness. (d)21 days from onset of illness.

Figure 3: Correlations between: The days of nucleic acid test turned negative and lymphocytes;

Figure 4: Correlations between: Time from onset of symptoms to confirmation of diagnosis and Time it took for symptoms to improve. 







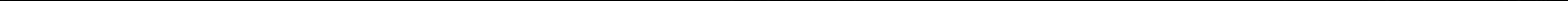









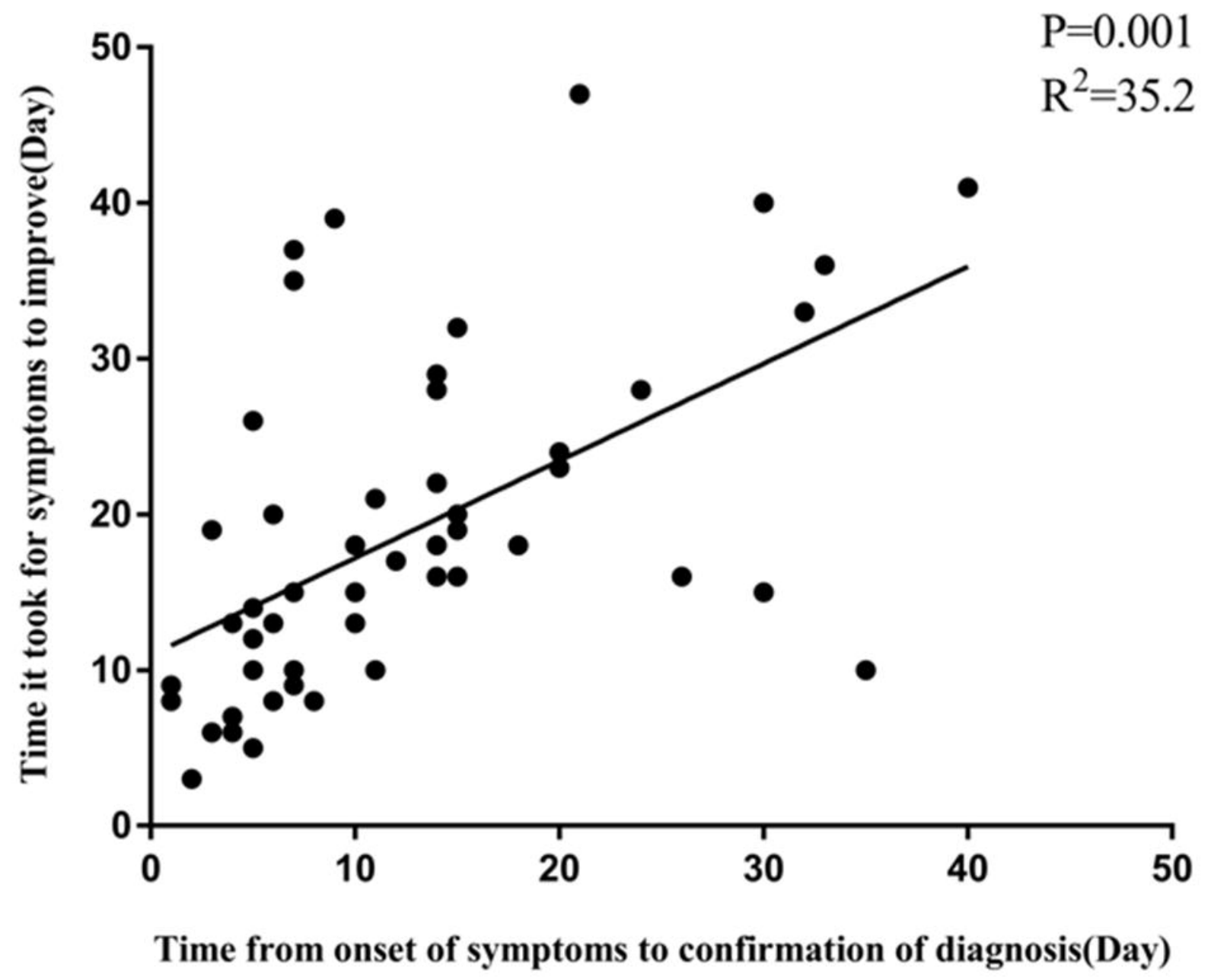

